\title{
Vanaheebrea afektiivse ja reflekteeriva mureluule stroofistruktuurist liobi kõnede näitel
}

\author{
URMAS NÕMMIK
}

\section{Vanaheebrea mureluule}

Poeetika mõistet mureluule pole piibliluule ${ }^{1}$ kohta veel kasutatud. Sellel on mõtet, kui tunnistada pika ajalooga žanriloolist probleemi: žanride piirid ei jookse mitte mööda piibliheebrea luule suuri korpusi, nagu psalmi-, prohveti- või tarkuskirjandus, vaid risti ja põiki läbi nende. Üks piibliraamat ei esinda kunagi ühte või mitut ainult sellele raamatule omast žanri, vaid sellesse on laenatud ja segatud paljusid. Võib rääkida väiksematest genuiinselt psalmilikest, prohvetlikest ja tarkuslikest žanridest, nagu kaebelaul, tänulaul, kiituslaul, õnnetusekuulutus, manitsus, vanasõna ja õpetuskõne, aga tuleb tunnistada ka, et nendest on alguse saanud mahukamad vanaheebrea tekstid ja kogumikud, mis on praegusel kujul peadpööritavad žanrisegud. Neid on sajandite jooksul pikitud vagade vahemärkuste ja glossidega, nõnda et nii genuiinseid kui ka laenatud žanre ja žanrifragmente on raske ära tunda. Selles segaduses aitab, kui püüda teha tekstides paremini vahet erinevatel kirjanduslikel kihistustel ja redaktsioonidel, panna tähele ka kõige väiksemaid vormierisusi, tuvastada žanrilisi algimpulsse ning otsida neid vajadusel ka väljastpoolt uuritavat teksti või luulekorpust.

Mureluule alla võiks esmajoones paigutada põhiliselt Psalmiraamatust tuntud kaebelaulu, mida Hermann Gunkel ${ }^{2}$ nimetas esimesena psalmide kolme põhižanri seas. Veel kitsamalt tuleks rääkida üksikisiku kaebelaulust, täpsemalt häda kirjeldavatest ja anuvatest lauluosadest, sest kaebelaulu usaldustunnistused, tänud ja tõotused ei tarvitse kajastuda teiste luulekorpuste kaebustega samas komplektis. Kaebelauludega on suguluses itk, hbr qina, mis on puhtamgi kaebus kui Psalmide kaebelaulud, ent mida esineb Heebrea Piiblis selgel kujul väga vähe, sest iseäraliku värsimõõdu ${ }^{3}$ on omastanud teistsuguse sisuga nooremad tekstid (Nõmmik 2016). Üksikuid itku näiteid leiab prohvetiraamatutest, aga kindlasti on itku najal kasvanud suurem osa Nutulaulude raamatu laule. Esmapilgul vabamas vormis kaebusi leidub

\footnotetext{
${ }^{1}$ Ehkki vanaheebrea luule viib mõtte esmalt piibliluule peale, on esimene mõiste laiem, hõlmates nii Vana Testamendi kui ka Surnumere käsikirjadest ja epigraafilistest allikatest tuntud luulet. Piibliheebrea luule on kitsamalt Vana Testamendi luule, mõiste piibliluule võib haarata lisaks ka Uue Testamendi üksikuid luuleosi ning Vana Testamendi luule tõlkeid kreeka keelde.

${ }^{2}$ Gunkeli psalmikommentaari esmatrükk ilmus 1933. aastal, tuntuim on selle neljas väljaanne (Gunkel, Begrich 1985).

${ }^{3}$ Suhteliselt lühikese bikooloni teine koolon on alati esimesest lühem, isegi kuni kolmandiku võrra.
} 
prohvetite, näiteks Jeremija raamatus, aga kindlasti ka Iiobi raamatu Iiobi kõnedes, mida peetakse tarkuskirjanduse osaks.

Mure ja luule on tänapäevasele piiblilugejale kõige tuntavamal ja tuntumal kombel ühendatudki just Iiobi raamatus. Selles luules muret ei varjata, see ongi luule teema. Heebrea sõna śīah 'mure' kasutatakse peategelase kõnedes viis korda (Ii 7,13; 9,$\left.27 ; 10,1 ; 21,4 ; 23,2^{4}\right)$ ning vastavat konsonantjuurt śjh ühel korral (Ii 7,11). ${ }^{5}$ Tunnussõna on paigutatud ühe teoloogiliselt väljakutsuvama liobi kõne algusesse, andes retoorilise küsimuse sees aimu mure üliinimlikust mõõtmest (Ii 21,4-5):6
4 he'ānokì lo'ādām śịhì vo'im-madd̄̄a'lo'-tiqșar rūḥ̄
5 panū-èlaj vahiššammū vaśìmū jād 'al-pē

\author{
Kas mu mure on inimese jaoks? \\ Miks ei peaks olema ma ärritunud? \\ Pöörduge mu poole ja 'jahmuge' \\ ning pange käsi suu peale!
}

Kui Iiobi kõned on mureluule, tuleb ka tõdeda, et kaebused on nendes tihedalt põimunud riidlemise, õiglusesoovi ja kaduvuse üle reflekteerimisega. Viimased teemad aitavad näha seoseid nii Vana Testamendi ülejäänud tarkuskirjandusega (Koguja, Õpetussõnad, apokrüüfidest Ben Sira [Jeesus Siirak] jne) kui ka muistsest Lähis-Idast tuntud eelkäijatega, eriti vaga kannataja motiivist lähtuvate teostega (Annus 2011; Nõmmik 2013: 29-31). Kõige parem ongi ehk pidada mureluule määratluse aluseks inimese eksistentsiaalset muret, sest kannatava inimese küsimus „miks?” sisaldab nii isikliku (miks mina?) kui ka universaalse kannatamise tasandit (miks üldse nii?). Tasub meenutada, et nii eesti kui ka heebrea keeles on mure mõistel lai tähendusväli. Afektiivse, ängist välja paiskuva mure kõrval on võimalik ka reflekteerivat, juurdlevat või ka eksistentsiaalset laadi tähendus: see, mis paneb mõtlema, mõttefookus.

\footnotetext{
${ }^{4}$ Viitamisel eristatakse komaga peatüki- ja salminumbreid, punktiga vajadusel salminumbreid ja semikooloniga peatükinumbreid.

${ }^{5}$ Sugulus Psalmiraamatu kaebelauludega ilmneb näiteks sama sõna kasutamisest teatud psalmide alguses (nt Ps 55,3; 64,2; 102,1; 142,3).

${ }^{6}$ Iiobi tekstide tõlked on esitatud Nõmmik 2013 järgi, aga neid on vajadusel kohandatud. Ülejäänud tekstid on samuti tõlkinud artikli autor. Vasakul on näidatud salminumbrid. Heebrea algteksti transkriptsioonides on püstkirja kasutatud juhul, kui vanima terviklikult säilinud Heebrea Piibli käsikirja ehk Leningradi koodeksi (lad Codex Leningradensis) teksti on parandatud, sama kehtib tõlgetes '...--märkide kohta; nurksulud [...] märgivad lisandusi Leningradi koodeksi tekstile ja <.> kohta, kus on välja jäetud Leningradi koodeksis asuvad sõnad või fraasid, mis ei ole kuulunud algsesse värssi. Paranduste põhjendusi vt Iiobi tõlke kommentaaride sektsioonist (Nõmmik 2013: 129-277). Transkribeerimisel on eeskujuks „Heebrea keele transkriptsiooni soovituslikud reeglid eesti keeleruumi jaoks" (2015), täpsemalt selle esimene versioon (lk 142) lihtsustatud kujul (ülilühikesed vokaalid on märkimata, pikad ja ülipikad on märgitud ühtemoodi ning $y$ ja $w$ on asendatud $j$-i ja $v$-ga).
} 


\section{Stroofidest vanaheebrea luules ja liobi raamatus}

Eksistentsiaalse mure teema alusel piiritletud mureluulet esineb mitmes vanaheebrea luule korpuses. Esmapilgul tundub mureluule vormiline pilt olevat kirju. Nagu juba eespool öeldud, võib mureluule sees eristada teistest vormidest vähemalt itku, sest sel on eriomane värsimõõt. Aga analüüsida võiks ka ühte teist vormivõtet, nimelt stroofi pikkust, sest stroofid võivad vanaheebrea luules olla nii kahe-, kolme-, nelja- kui ka viievärsilised (üks värss tähendab reeglina ühte bikoolonit, harvem ühte trikoolonit). Siinne artikkel tahabki mureluule kui žanri olemasolu väitmise kõrval eristada Iiobi mureluules kahte tüüpi stroofe ehk kolme- ja neljavärsilist stroofi, milles on vastavalt genuiinselt afektiivne ja genuiinselt reflekteeriv allhoovus. ${ }^{7}$

Vanaheebrea luule uurijad on sellise nähtuse nagu stroofi olemasolu ikka väitnud (Seybold 2003: 173-192; Nõmmik 2015: 18-23), sest seda kinnitavad refräänidega psalmid, nagu Ps 42/43; 46; 56; 57 ja 80, ning akrostihhonid, nagu Ps 37 või Nl 1-4 (Watson 1984: 160-200; van der Lugt 1995; Seybold 1996: 16-17; Alonso Schökel 2000: 40-41). ${ }^{8}$ Uurimine takerdub tihti kahel põhjusel. Esiteks julgevad liiga vähesed kirjandus- ja redaktsioonikriitika abil välja puhastada piiblitekstide vanemaid kihistusi või nende fragmente. See, et stroofid on poeemide varaseimates versioonides olnud tasakaalustatud ja regulaarsed, on uurimisloos kindlasti alahinnatud tõdemus. ${ }^{9}$ Teiseks kaheldakse stroofides seetõttu, et uurijatel pole kusagilt võtta füüsilisi tõendeid. Keskaegsetes käsikirjades markeeriti küll sisuliste tekstiühikute algusi vahetevahel taandridadega ning Surnumere käsikirjades pikemate tühikutega (lad vacat) ja nii mõnigi kord langevad need kokku stroofipiiriga selle klassikalises mõttes, aga laias plaanis ei paku käsikirjad meile kuigi palju silmaga nähtavaid tõendeid. Näiteks tõdeb Luis Alonso Schökel (2000: 41), et „[m]eie range „stroofi” idee nõuab värsside identse grupi, näiteks kolmikute või nelikute kordumist", aga ei tunnista, et ta jääb ise algsete stroofide väljapuhastamisega kimpu, sest ei soovi analüüsida tekstikihistusi diakrooniliselt. Hästi kaalutletud suhtumist esindab seevastu Klaus Seybold (2003: 191-192), kes jõuab järeldusele, et psalmides on tegemist „läbinähtava tekstiplaneeringuga", ning juhul kui see ei paista (kohe) välja, on põhjuseks kas a) uuritava teksti proosavorm, b) vanema teksti hilisem pragmaatiline töötlus, mis kahjustas või hävitas varasema struktuuri, või c) ei ole see veel avastatud, kuna vormikeel on tundmatu.

\footnotetext{
${ }^{7}$ Ma ei tea ühtegi sarnast käsitlust, ehkki liobi dialoogi kõnede vormi on kirjeldatud küll erinevatest vaatepunktidest. Ühe mõjukamana olgu esile tõstetud Claus Westermanni (1956) käsitlus, mis jaotab kõned väikežanridesse, lähtudes psalmižanridest.

${ }^{8}$ Ingliskeelses kirjanduses kasutatakse stroofi kohta tihti sõna stanza, mõnikord jällegi moodustavad väiksemad stroofid (strophe) suurema ühiku stanza (Watson 1984: 160-200). Hollandi poetoloogia koolkonnas kasutatakse sõna strophe, ent stroofid moodustavad poeemi sees mitu canto't ning vajadusel rakendatakse veel vahetasandit nimega subcanto (van der Lugt 1995: 33 jm).

${ }^{9}$ Seepärast ei pea imestama, et siinses artiklis väidetud stroofid lahknevad tihti nt van der Lugti (1995) Iiobi kõnede analüüsist.
} 
Olen jõudnud Seyboldist sõltumatult sarnasele seisukohale Iiobi sõprade kõnede (Ii $4-5^{\star 10} ; 8^{*} ; 11^{\star} ; 15^{\star} ; 18^{\star} ; 20^{*}$ ja $22^{\star}$ ) vanimaid versioone uurides: nende autor on enamasti sidunud kahest reast koosnevad värsid ehk bikoolonid paarikaupa kokku (Nõmmik 2010: 85-88). Üks teema, üks lause, üks võrdpilt jne hõlmab reeglina kaks värssi, kaks bikoolonit. Mõnikord ulatub teema, võrdpilt või isegi lause üle kahe värsipaari, mida rõhutavad ja kinnitavad teisedki poeetilised võtted - sel juhul saab rääkida tavalisest stroofist, mille pikkus on kaks värsipaari ehk neli värssi. Nõnda on kujundatud Iiobi sõprade kaheksast algsest kõnest pooled (Ii $8^{\star} ; 11^{\star} ; 20^{\star} ; 22^{\star}$ ). Ülejäänud eelistavad viievärsilisi stroofe, mille alastroofid on koostatud erinevate mustrite järgi $(2+3,3+2,2+2+1$ jne $)$.

Jumal kõneleb Iiobi algses dialoogis ühe korra (Ii 38,1-39,30*) ja see kõne on koosnenud algselt kindlasti neljavärsilistest stroofidest, nagu väidan oma redaktsiooniloolises mudelis, mis on ka siinse artikli eelduseks (Nõmmik 2013: 263-268). ${ }^{11}$ Iiobi enda kõnesid on aja jooksul kõige rohkem täiendatud ja ümber vormitud, mistõttu on nendes kunagist reeglipärast stroofistruktuuri kõige raskem avastada. Kindlasti on mitu kõnet algselt neljavärsiliste stroofidega: Iiobi teine vastus sõpradele Ii $9-10^{*}$, kolmas vastus Ii $12-14^{*}$, viies vastus Ii $19^{*}$, kuues vastus Ii $21^{*}$ ja osa seitsmendast vastusest Ii $23^{*}$. Samal ajal kirjutati mitu kõnet algselt kolmevärsiliste stroofidega: avakaebus Ii $3^{\star}$, esimene vastus Ii $6-7^{\star}$ ning neljas vastus Ii $16-17^{\star}$. Kui hilisemad täiendajad on lisanud Iiobi kõnedesse pikemaid terviklikke poeeme, siis vaatab neist vastu nii läbivalt kolmevärsiliste (Ii $12,7-25^{\star}$ ) ja läbivalt neljavärsiliste stroofidega (Ii 9,3-14; 30-31*; 40,7-14; 40,25-41,26*) kui ka komplekssema struktuuriga poeeme (Ii 7,1-10.11-18*; $24^{*} ; 26 ; 27,7-10.13-23^{*} ; 28^{*} ; 32-37^{\star}$ ).

Mõnda tuleb enne järgnevat ülevaadet veel teada. Esiteks iseloomustab Iiobi kõnede algseid kolme- ja neljavärsilisi stroofe see, et need koosnevad ainult kaheosalistest värssidest ehk bikoolonitest, mis on pealegi tavaliselt kantud mõtteriimist. Trikoolonid on alati redigeerijate kätetöö tulemus (Witte 1994: 58; Nõmmik 2010: 89). Teiseks tuleb jälgida kolomeetriat ehk konsonantide arvu värsis. Vanimas kihistuses olid värsid reeglina tasakaalus, st üliharva erines kahe kooloni pikkus rohkem kui kolm konsonanti (tavaliselt nt 15:12; 13:14 jne), tüüpiliselt näiteks stroofi alguses või lõpus (Nõmmik 2010: 89-91). Pisitäiendused, glossid ja suuremad redaktsioonid tõid kaasa selle, et värsid läksid aja jooksul tasakaalust välja. Peale selle tasub kriitiliselt hinnata, milline on keskmine kooloni pikkus stroofi kohta või koolonite suhe üksteisega, sest Iiobi luule erinevad autorid võisid värsse või üksikuid kooloneid

\footnotetext{
${ }^{10}$ Tärni kasutatakse piibliteadustes, kui mõeldakse vastava kirjakoha vanimat, lisandustest vaba kuju.

${ }^{11}$ Siinne artikkel võtab aluseks diakroonilise, piibliteaduste keeles redaktsioonikriitilise lähenemise ning näeb ühes ja samas piiblitekstis reeglina mitut kirjanduslikku kihistust, mitut autorit. Iiobi kommentaari eessõnas (Nõmmik 2013: 27-29) on visandatud Iiobi raamatu tekkeloo mudel, milles on eristatud dialoogiosa algset kihistust ja autorit ( $c a$ IV saj eKr) ning vähemalt üheksat nooremat kihistust ja autorit ( $c a$ IV-II saj eKr), mille hulgas on tähtsaimad need neli (paraku anonüümset) redigeerijat, kes rõhutavad majesteetlikkust, õiglust, kaduvust ja alandust. Siinse artikli raames piisab sellest, kui eristada varasemat ehk vanemat ehk algset dialoogi ning laias plaanis selle hilisemaid ehk nooremaid täiendusi. See tähendab ka seda, et kui tsitaatides on jäetud üksikuid salme vahele, siis ei kuulunud need algsesse teksti, vaid on lisatud hilisemal ajal ning on rikkunud algse värsi või stroofi struktuuri.
} 
kord pikemaks venitada, kord kokku suruda. Ka pole vähetähtis, et nooremas Vana Testamendi psalmi- ja prohvetiluules võib esineda nn pööratud qina värsimõõtu (Watson 1984: 98; Nõmmik 2015: 10-11, 14), kus värsside esimesed koolonid on läbivalt teisest lühemad. Seda tuleb ette ka Iiobi raamatus, nt allpool tsiteeritavas kaduvuse poeemis Ii 14,1-2.5-10, mis on kellegi Iiobi täiendaja kätetöö. ${ }^{12}$

Stroofide markeerimisel ${ }^{13}$ mängivad olulist rolli sõnakordused, sünonüümsed loetelud, süntaktiline mõtteriim ning algriim. Järgnevates näidetes raamib sõnakordus tihti stroofi või lühipoeemi kahte stroofi, üks ja sama sõna võib kuuluda sümmeetriliselt ühe stroofi mõlema värsipaari ehk alastroofi algusesse, ka vastandsõnad võivad raamida lühipoeemi või vähemalt teemaarendust selle sees ning algriim võib siduda kokku värsipaaride algused jne. Nimetatud tähistamisviise on meil tänapäeval kõige lihtsam tajuda ning nad on seega väravaks vanaheebrea luulekeele enesele osutava funktsiooni juurde. Selle värava taga on veel palju poeetika nüansse, mille kohta annavad aimu mahukamad vanaheebrea poeetika käsitlused (nt Watson 1984; Alonso Schökel 2000), mõningaid neist olen puudutanud oma eestikeelses lühiülevaates (Nõmmik 2015).

\section{Kaebus ja afektiivne mureluule}

Kõige tavalisem Iiobi kaebus tähendab häda kirjeldust võrdpiltide abil. Ainuüksi oma kannatuse lausumine pakub ventiili, mille kaudu häda koormat vähendada. Hääle tegemine aitab, veel rohkem aga kõne, millel on teatav rütm ja häälikulisus ning mille taga on aastasadadepikkune traditsioon. Kõlaliselt ilmselt kõige kõrvulukustavam stroofipaar Iiobi kõnedes on neljanda vastuse kolmas ja neljas stroof (Ii 16,12$16^{*}$ ), sest $p$-, $r$ - ja s $s$-häälikute tihe vaheldumine, sekka rida topeltkonsonante ja silbikordusi, on viidud äärmuseni, tipnedes salmis 14a kolmekordse $p$-r-s-iga:

12

šälèv hàjìtì vajaparparēnì

va’āhaz bo 'årpì vajapaṣpașēnī

<.>jaqìmēnì lō lamatțāāā

$13^{14} \quad$ [va]jāsobbū 'ālaj rabbav

japallah kiljōtaj valo' jahmōl

jišpok lāāareș marērātī
Segamatult olin, aga Ta raputas mind

ja haaras mu kõrist ning põrmustas mind;

$<.>$ Ta tõstis mind omale sihtmärgiks

[ja] ümbritses mind oma nooltega;

Ta lõhestas mu neerud kaastundeta,

kummutas maa peale mu sapipõie.

\footnotetext{
${ }^{12}$ Hilise piibliheebrea luule näite (Ps 86) poetoloogilist analüüsi vt Nõmmik, Põldsam 2018.

${ }^{13}$ Stroofe piiravate poeetiliste markeritega tegeleb iseäranis põhjalikult van der Lugt (1995, vt loetelu lk 41-42), aga ka Watson (1984: 160-200).

${ }^{14}$ Uusaegsete tekstiediteerijate lisatud salminumbrid järgivad keskaegsete masoreetide rõhu- ja struktureerivaid märke - kummalgi puudub otsene kontakt kaks tuhat aastat tagasi kõlanud luulekeelega. Salminumbrid ei vasta seega alati luule vormile.
} 
14 jiprașēnī pereș 'al-panē-pāreș jāruṣ 'ālaj kagibbōr

15 śaq tāpartī 'alē gildī va 'olaltì be 'āpār qarnì

16 pānaj ḥåmarmarū minnī-bekī va'al 'ap' 'appaj șalmāvet
Ta murdis mind, murd murru peale, Ta ruttas mu vastu nagu vägilane; koti(riide) õmblesin oma naha peale ja pistsin põrmu oma sarve; mu pale muutus punaseks ${ }^{15}$ nutust ja mu särasilmile (tuli) surmavari.

Esimene fraas kinnitab, et Iiob elas kunagi rahus, aga kohe samas värsireas raputatakse kuulajat kõlaliselt agressiivse avanguga vajoparparēnī 'aga Ta raputas mind' järgnevale loetelule Jumala jõhkruste kohta. Viimane sõna surmavari võtab kõik kokku. Füüsiline häda on nii suur, et see ei lase vait olla: häda kirjeldamiseks tuleb leida üha uusi ja uusi sõnu. Vormiliselt torkab silma kolmevärsiline stroof, mis algab ühe sissejuhatava bikooloniga ja jätkub võrdpilti kasutava värsipaariga. ${ }^{16}$

Ka Iiobi esimeses vastuses (Ii $6-7^{\star}$ ) on hulk märke sellest, et see koosnes algselt kolmevärsilistest stroofidest, olgu tsiteeritud selle esimese poole teine pool (Ii 6,8-13*):

$8 \quad$ mī-jittēn tābō's še elàtī

vatiquātī jittēn 'elōah

9 vajo'èl 'èlōah vìdakka'ēnī

jattēn jādō vìbașșa 'énī

$10 \bar{u}$ tahì 'ōd nehāmātì

va'asalladā <.> lo' jaḥmōl

$11 m \bar{a}-k o h \bar{i} k \bar{k}$-'ajahè $l$

ūmā-qișșì kì-'ảarìk<.>

12 'im-koaḥ 'abānìm koḥi

'im-baśārī nāḥ̄ūš

13 ha'im 'ēn 'ezrātī bì

vatušijjā niddahā mimmennī
Oh et ometi mu palve saaks vastuse

ja mu lootusele vastaks Eloah;

ja et otsustaks Eloah ja muljuks mind,

liigutaks oma kätt ja tükeldaks minu!

Siis oleks veel mul lohutust

ja hüpleksin $<.>$, kaastundeta.

Mis jõud mul on, et veel ootan,

ja mis lõpp mul, et veel kestan? <.>

Kas kivide jõud on mu jõud,

kas mu ihu on pronksist?

Kas siis polegi mul abi Sinust

ja mõistuski peletatakse minust?

Äraspidisena mõjub palve (šəèlā) mis loodab Jumalalt surma ning väidab rea retooriliste küsimuste abil, et Iiobi - või tegelikult mitte ühegi inimese - jõud ei saa olla nii suur, et jaksaks sellises kannatuses mõistuse juures püsida. Kesise inimliku jõu argument on tugev, ent kasvab just nõnda - esimeses pöördes sõnastatuna välja tundest, füüsilisest ja vaimsest väsimusest. Toon on selgelt afektiivne ning seda rõhutatakse kolmeste ehk lühikeste stroofidega. Sarnaselt eelmise näitega raamitakse

\footnotetext{
${ }^{15}$ Või paisus, vt allmärkust 24.

${ }^{16}$ Pane tähele teise stroofi markerina sõna pānē 'pale', mis esineb nii eessõna funktsioonis (14a) kui ka nimisõnana (16a).
} 
stroofipaari võtmesõnaliselt lootusega (tiqvā), mis on Iiobil, ning abiga ('ezrā), mida Jumal ei anna. ${ }^{17}$

Kõige tuntum ja sugestiivsem Iiobi kõnedest on avakaebus (Ii 3), mille vanim versioon on kindlasti koosnenud kolmevärsilistest stroofidest. Kõne kaks esimest algset stroofi (Ii 3,3.7-8*.10-12), mida Oswald Loretzi (2000) avastuse kohaselt on hilisemal ajal täiendatud omaette ja hoopis neljast trikoolonist koosneva poeemiga (Ii 3,4-6.9), nägid ilmselt välja järgnevad:

$3 \quad$ jōbad jōm 'ivvāled bō vahallajlā 'āmar horā gāber

7 hinne <.> jahī galmūd 'al-tābo' ranānā bō

8

$10 k i ̄ l o ’$ sagar daltē biṭnì vajjastèr 'āmāl mēe énāj

11 lāmmà lo' mèrehẹem 'àmūt mibbeten jāṣātī va'egvā'

12 maddūa' qiddamūnī birkājim ūmā-šāddajim kì 'iñāq
Kadugu päev, mil mind sünnitati, ja öö, mil öeldi: mehepoeg on eostatud!

Ennäe, see <.> olgu viljatu, ärgu tulgu rõõmustamine selle juurde!

Sajatagu seda päeva needjad, kes valmis äratama Livjatáni.

Jah, see ei sulgenud mu emaihu ust ega peitnud vaeva mu silme eest! Mispärast ei surnud ma emaüsas juba, väljudes emaihust kustunud ma; misjaoks kohtasid mind põlved ja miks rinnad, et imeksin?

Jälle on näha selgelt markeeritud kolmevärsiliste stroofide paari, ${ }^{18}$ kusjuures mõlema stroofi algusvärsist (3 ja 10) vaatab vastu vastupandamatu soov, et kaoks (jōbad) vaev ( 'âmāl). Sellist sügavalt afektiivset teksti võiks nimetada ka kaosooviks. Võib-olla on see olnud isegi omamoodi pisižanr, aga kindlasti on see vähemalt vihje needustele ja sajatustele, milliseid pidi kasutatama palju, sest viiteid manapraktikatele on muistsest Lähis-Idast teada küllaldaselt. Heebrea Piiblis on veel üks tuntud oma sünnipäeva needmise näide Jeremija raamatus 20,14-18, mida on tihti nimetatud Iiobi avakõne paralleelina (Bright 1965: 134). Tonaalsus on seal sarnane, aga vorm vastavalt prohvetikirjanduse kirjule stiilile mitmekesisem. Kahekordsele ütlusele 'ārūr 'neetud olgu' salmides Jr 20,14-15 järgneb oma kunstipärasuse poolest Iiobi avakõnega võrreldav teemaarendus (Jr 20,16-18):

\footnotetext{
${ }^{17}$ Pane tähele värsipaare markeerivaid sõnu 'elōah 'Eloah (Jumal)', ntn 'andma' (Ii 6,8-9) ja koah 'jõud' (Ii 6,11-12) ning teist stroofi valitsevaid küsisõnu $m \bar{a}$ 'mis' ja im 'kas'. Sarnaste kolmevärsiliste stroofide näited on veel Ii 3,20-22.24-26; 6,2-7*; 16,7-9*; 17,13-15.

${ }^{18}$ Esimest stroofi raamib teemasõna jōm '(sünni)päev' (salmides 3 ja 8 - kui see on kindel salmis 8 , sest Loretz (2000) tahab seda korrigeerida jam'iks 'meri') ja teist partikkel $k \hat{\imath}$ ' jah/sest' (salmides 10 ja 12); kummagi stroofi värsipaare tähistavad isikusufiksiga varustatud eessõna $b o ̄$ 'selles' (salmides 3 ja 7) ja sõna bețen 'emaihu' (salmides 11 ja 12).

${ }^{19}$ Codex Leningradensise Jeremija raamatu 20,16 tekstis ei sobi vəhājā hā' nagu...' kokku salmi 17 mõttega, seega tuleb muuta hä'iš 'mees' sõnaks hājjōm 'päev', muuhulgas
} 
'ašer-hāpak jhvh valo' nihām

jišma'za 'àqà babboqer

ūtarū 'ā bə 'êt șåhårājim

17

'ašer lo'-mōtatanì mērāhem

vattzhī-lì 'immī qibrī

varaḥmā harat 'ōlām

18 lāmmā zē mērehem jāṣātī

lirōòt 'àmāl vajāgōn

vajjiklū babošet jāmāj mille Jahve pööras segi, lohutamata -

'kuulaku' see ${ }^{20}$ hädakisa hommikul

ja sõjakisa keskpäeva ajal! -

mis $^{21}$ ei surmanud mind emaüsas ${ }^{22}$,

nii et mu ema oleks olnud mu hauaks

ja ta emaüsk lapseootel igaveseks.

Miks ma küll emaüsast väljusin,

et näha vaeva ja leina

ja et mu päevad lõppeksid häbis?

Sarnasusi Iiobi needmisega on nii palju, et kahtlustatud on lausa kirjanduslikku sõltuvust üksteisest (Rudolph 1958: 123; Schmidt 2008: 339) või vähemalt ühist eeskuju (Westermann 1956: 32-33). ${ }^{23}$ Fakt on, et Jeremija kirjakoht sisaldab nii kolmevärsilise stroofi ideed sarnaselt Iiobi algse avakõne vormiga - küll koos prohvetikirjandusele iseloomuliku sissejuhatava monokooloniga - kui ka sarnasust Iiobi avakõne ülal nimetatud hilisema täienduse vormi ja sisuga (Ii 3,4-6.9), mis koosneb trikoolonitest ning algab peaaegu sõna-sõnalt samamoodi nagu Jr 20,16a (vrd Ii 3,4a).

Iiobi kaebustes kasutatav kolmevärsiline stroof ei ole juhuslik: see ongi iseloomulik vanaheebrea kaeblemisele. Sellele leiab kinnituse Nutulaulude raamatust, mis on nii judaistlikus kui ka kristlikus traditsioonis tagantjärele omistatud Jeremijale. Raamat koosneb akrostihhonitest, sarnanedes vormi poolest hulga vastavate psalmidega. Iga nutulaul koosneb kas 22 värsist või 22 mitmevärsilisest stroofist ning stroofide esitähtedest tuleb kokku heebrea tähestik. Sealjuures koosnevad kolm esimest nutulaulu 22 kolmevärsilisest stroofist (paari erandiga). Kõik värsid on bikoolonid või on seda algselt olnud. Paremat tõestust sellele, et nutu- ehk kaebelaulu traditsioonis on tendents kasutada kolmest bikoolonist moodustatud stroofe, on raske leida. See on isegi olulisem kui itku värsimõõt, sest stroofide pikkus on järjekindlam kui värsimõõt. Olgu siin tsiteeritud teise ehk vanima nutulaulu (Kaiser 1992: 105; Witte 2006: 466-468) $k$ - ja $l$-stroofid, mis kirjeldavad häda (Nl 2,11-12):

11 kalu baddomā 'ōt 'énaj
ḥåmarmorū mēe'aj
Kustuvad mu silmad pisarais, paisub mu sisemus;

Iiobi paralleelide põhjal, rääkimata verbi $h j h$ 'olema' muutmisest tavaimperfekti vormist jussiiviks (Rudolph 1958: 122; vrd seevastu Schmidt 2008: 338).

${ }^{20}$ Mõeldakse päeva, mitte linnu; verbi on parandatud vanade tõlgete põhjal (Rudolph 1958: 122; Bright 1965: 130).

${ }^{21}$ Vt eelmist märkust.

${ }^{22}$ Ehkki vanade tõlgete põhjal tahetakse eessõna tihti parandada (Rudolph 1958: 122; Schmidt 2008: 338), võimaldab Iiobi paralleel ka praeguse eessõna min säilitamist (vrd Bright 1965: 130).

${ }^{23}$ Kirjakohti seovad sõnad jōm 'päev', rehem 'emaüsk', mvt qali verbitüves 'surema' / poleli verbitüves 'surmama' ja 'āmāl 'vaev' (Ii 3,3.10-11), aga ühest teisest Iiobi kõnest ka sõnad nehạmā 'lohutus' / nhm nifali verbitüves 'lohutama' (Ii 6,10). 
nišpak lāàreș kabēdi

'al-šeber bat-'ammī

bē'ātẹp 'ōlèl vajōnēq

birhobōt qirjā

12 la'immotām jōmrū

'ajjē dāgān vājājin

bəhit'aț̣apām kehāāāl

birhobōt 'ì

bahištapēk napšām

'el-ḥeqq'immotām kummutatud maa peale mu maks

mu rahva tütre murdumise pärast,

kui väikelaps ja võsu nõrkevad

linna väljakutel.

Oma emadele nad ütlevad:

„Kus on vili ja vein?”,

kui nad nõrkevad nagu läbitorgatu

linna väljakutel,

kui nende hinged end kummutavad oma emade sülle.

Sarnaseid nutulaule lauldi vanas Lähis-Idas (juba vanas Sumeris) vallutatud, rüüstatud või hävinud linnade pärast. Tekstinäites on mureks Jeruusalemm, mida isikustatakse („mu rahva tütar”) ja mistõttu on võimalik kasutada samasugust metafoorikat nagu Iiobi kõnedes: siseorganid valatakse maha (N12,11c ja Ii 16,13c) ning silmad või sisemus paisuvad/paistetavad (Nl 2,11a-b ja Ii 16,16a) ${ }^{24}$ Nutulaulu näidet eristavad Iiobi näidetest itku värsimõõt ning tava mitte kasutada koopulat və- iga teise kooloni alguses, aga häda ja sellega kaasneva füüsilise reaktsiooni kirjeldus on väga sarnane Iiobi kõne omaga, rääkimata kolmevärsilistest stroofidest või raamimise võttest, mida tunnussõna 'immotām 'nende emad' kujukalt näitlikustab (Nl 2,12a+f). Siinkohal saab esile tuua ka kaebelauludest tuntud senise (hea) ja praeguse (häda) terava vastandamise võtte (Kaiser 1992: 102; Nõmmik 2016: 436), mis väljendus hästi eespool toodud häda kirjelduse näites Ii 16,12-16*, aga peegeldub tihti ka Iiobi raamatu retoorika meelisväljendis $k \bar{i}$ - 'atta 'aga nüüd' (Ii 3,13; 6,21; 7,21;30,1.9.16). Märkimata ei saa jätta sedagi, et nutulaulude värsid on qina värsimõõdu mõjul kolomeetriliselt väga lühikesed; selline nutu- ja kaebelaulude tendents selgitab ka Iiobi näidetes alatasa esinevaid keskmisest pisut lühemaid värsse. ${ }^{25}$

\section{Murelik õiglusesoov ja riiukõne ning reflekteeriv mureluule}

Neljavärsilistest stroofidest koosnevates kõnedes domineerivad õiglusesoov ja riidlemine. Esimene flirdib avalikult kohtukõne žanriga, kasutab juriidilist terminoloogiat (șdq 'õige olema', rš' 'süüdi olema', nqh pieli verbitüves 'süütuks tunnistama',

\footnotetext{
${ }^{24}$ On tähelepanuväärne, et Heebrea Piiblis esinevad kahe tähendusega verbi $h m r$ pealali tüve vormid üldse vaid Nutulaulude $(1,20 ; 2,11)$ ja Iiobi raamatus $(16,16)$; tähenduseks sobivad nii 'paisuma, paistes olema' kui ka 'punaseks muutuma'.

${ }^{25}$ Võrdle NI 2,11-12 kolomeetrilist keskmist $(10,5)$ Iiobi näidetega Ii 6,8-13* (keskmine 12,67) ja Ii 3,3.7-8.10-12 (keskmine 13,33). Heebrea Piibli psalmide ja prohvetikirjanduse nii vanematest kui ka noorematest kihistustest on kindlasti võimalik leida veel palju näiteid kolmevärsilistest stroofidest, mis sobivad afektiivse luule raamesse, vt nt Ps 22,4-6.7-9.10-12*.20-22 (vt lisa Nõmmik 2009); Ps 73,1b-3.18-20.21-23; 90,3.5-6*.7-9*; 102,2-3.4-6.7-9.10-12; 142,2-4b.4c-5 või Js 1,$11 ; 5,20 ; 10,1$.
} 
špt 'kohut mõistma' ja mišpat 'kohus, õiguskord') ning on sügavalt otsustavat ja nõudlikku laadi. Iiob nõuab õiglast kohtlemist ning ei pelga esitada Jumalale kohtukutset. Või siiski pelgab? Iiobi kõnede varaseimal autoril (vt allmärkust 11) on õnnestunud parafraseerida kohtukõnet sellega, et ta kasutab ühelt poolt traditsioonilist kartmatut stiili ja juriidilisi keelendeid, teiselt poolt kombineerib seda aga murekõne ja hirmuga. Iiob kõiguks justkui kahevahel, kas kaevata Jumal kohtusse või mitte. Selles väljendub Iiobi poeedi kõige erilisem võte, refleksioon selle üle, et Jumal peaks vastutama. Sellest, et selline õiglusesoov kuulub mureluule hulka, annab märku sõna śīah 'mure', mida kasutataksegi Iiobi raamatus esimest korda liobi kolmandas kõnes (Ii 9,27; 10,1). Algselt neljastroofilise kõne (Ii 9-10*) kaks esimest stroofi (Ii 9,1516.19-20; 9,27-28.30-31) on ilmselt välja näinud järgmiselt:

15

<.> 'im-ṣādaqtī lo' 'e 'nē

limšopțì ethannān

16 'im-qārä̀tī vajja 'anēnī

lo'-'a'amīn kì-ja'azìn qōlì

19 'im-lakoah 'ammīṣ hinne va’im-lamišspāt mī jō ‘ìdēnì

20 'im-'eșdāq pī jaršī ‘ènī tām-'ānì vajja 'qəšēnī

27

'im-'āmartī 'eškohạ śị̂̂̄ 'e 'ezbā pānaj va'ablīgā

28 jāgortī kål- 'așşabotāj jāda 'tī kī-lo' tonaqqēeī

30 'im-hitrāhaștī bamēe-šàleg vahazikkōtī babor kappāj

31 'àz baššahat tițbolènì vati 'abūnī śalmōtāj
<.> Kui ka õigus mul, ei saaks ma vastata, oma kohtupidajat pean anuma;

kui ka hüüaksin ja Ta vastaks mulle, ei usu, et teritaks Ta kõrvu mu hääle peale.

Kui asi on jõus, siis on Ta tugev, ennäe, ja kui kohtus, siis kes kutsub mind sinna?

Kuigi õigus mul, mu suu jätab mu süïdi, täiuslik olen, siis peab Ta mind kõveraks.

Kui 'ma ütlesin': „Unustaksin oma mure, jätaksin oma palge ja muutuksin helgeks", tundsin hirmu kõigist oma valudest, teadsin, et sa ei tunnista mind süütuks.

Kui pesin ennast lumeveega ja puhastasin leelisega oma pihkusid, siis solgiauku sa kastsid mind ja jälestasid mind mu vammused.

Stroofe markeerivad nii värsipaarid kui ka vormivõtted, ${ }^{26}$ samuti tingimuslausete abil rõhutatud paratamatus, mis väljendub eriti selgelt protasise ehk tingimuse 'im-șādaqtī 'kui ka õigus mul' ja apodosise ehk järelduse pī jarš̄i 'ēnī 'jätab mu suu mind süüdi’ vastandamises. Kohtukõne murelik parafraas annab kõnele omalaadse eksistentsiaalse-reflekteeriva värvingu. Refleksioon seisneb selles, et Iiob analüüsib oma olukorda kui kohtukaasust ja veendub, et ta jäetakse süüdi.

\footnotetext{
${ }^{26}$ Partikkel 'im 'kui' markeerib tervenisti esimest stroofi $(15 a+16 a+19 a \cdot b+20 a)$ ning teise stroofi mõlemat alastroofi $(27 a+30 a)$, verb șdq 'õige olema' raamib esimest stroofi $(15 a+20 a)$, špt 'kohut pidama' tähistab kahte alastroofi $(15 b+19 b)$, verb ' $n h$ 'vastama' esimest alastroofi $(15 a+16 a)$. Ohtralt on algriimi ja häälikumängu (nt topelt-nn 15b+19a või $m$-hääliku kordus koos partikliga 'im). Partikli 'im üleküllusega tahetakse osutada juriidilistele, eriti kasuistliku õiguse tekstidele, vt nt Lepinguraamatut Ex (2Ms) 20,22-23,33, kus iga kaasus avatakse protasisega, mille alguses seisab 'im.
} 
Käsitletud Iiobi teises vastuses sõpradele (Ii 9-10*) nõuab Iiob põhimõttekindlalt õigust. ${ }^{27}$ Kui Iiob vaidleb siin Bildadiga selle üle, kas Jumal painutab õiguskorda (vrd Ii 8,3 ja 9,20), siis laieneb selline põhimõttelisem ja universaalsem fookus teistelegi kõnedele, kus kasutatakse neljavärsilist stroofi. Õiguse nõudmise kõrval on oluline teema riid: tegusõnad $r j b$ 'riidlema, vaidlema' ja $j k h$ hifili verbitüves 'korrale kutsuma' iseloomustavad tekste nii tugevasti, et sobiksid vastavat väikežanri näiteks pealkirjastama riiukõnena. Sõnaraamatu järgi on $r \bar{\imath} b$ 'riid' muuseas üsna juriidiline termin, käies teatud kaasuste ehk riiuasjade kohta (Gesenius 2009: 1239-1240).

Iiobi kõnede spetsiifiline kontekst sunnib riiukõnet käsitlema murekõne ühe vormina. Läänesemiidi maailmas tunnistati inimese eksistentsiaalse mure vägevust ja sellest tulenevalt kasutati eri viise, et mure raskust kuidagi kehast eemaldada. Kui keegi tuleb muretsejale ütlema, et ta on oma saatuses ise süüdi, siis ei sobi see konteksti, mis ütleb, et häda ja viletsus on vältimatud. Füüsiliselt aitab, kui ütlejaga riielda.

Iiobi algse kolmanda vastuse esimese stroofi (Ii $\left.12,2-3^{\star}+13,5-6\right)$ rekonstruktsioon näeb välja järgmine:

\section{2,2 'àmanām kī 'attem- 'àm va 'immākem tāmūt håkmā \\ 3 gam-lì lebab kamōkem lo'-nopēl 'ānokì mikkem <.> \\ 13,5 mī-jittēn haharēš taharī̌šùn ūtəhī lākem lahåkmā \\ 6 šim 'ū-nā' tōkahtì varibōt śapātaj haqǔ̌ibū}

\author{
Tõega, jah, teie olete rahvas, \\ ja teiega sureb tarkus; \\ ka mul on süda nagu teil, \\ ei ole minagi vähem teist <.>. \\ Oh et ometi küll vaikiksite \\ ja et saaks teile osaks tarkus; \\ kuulake nüüd mu korralekutsumist \\ ja mu huulte riidlemisi märgake!
}

Kõne avang viitab universaalsele teadmisele ( $h a ̊ k m \bar{a}$ 'tarkus'), aga tipneb riidlemisega (tōkahat 'korralekutsumine' / rīb 'riid'); järgneva kõne toonis ei pea seega kahtlema. ${ }^{28}$ „Olge vakka! Sest teie tarkus pole minu omast parem," võiks kokku võtta Iiobi sõnu, mis sobivad eksistentsiaalseks riidlemiseks hästi.

Tarkus håkmā sunnib otsima ja leidma toetust tarkuskirjanduse klassikalistest tekstidest. Kõigepealt võiks nimetada näiteid nendest Iiobi sõprade manitsuskõnedest Ii $8^{\star} ; 11^{\star} ; 20^{*} ; 22$, mis kasutavad neljavärsilist stroofi, aga need on pärit sellestsamast liobi dialoogist. Efektsemaid näiteid võiks leida Õpetussõnade raamatust, ent viimast on jällegi palju redigeeritud ja tekst pole nii kindel. Mõjuvaim on ehk Ben Sira (Jeesus Siiraki) tarkuseraamatu kõige vanem, Masadast leitud käsikiri.

\footnotetext{
${ }^{27}$ Kõne kahest neljavärsilisest stroofist koosnev teine kolmandik $(9,32-35 ; 10,1 b-c .3 a-b .6-7)$ pöördub avatult Jumala poole, kurdab võimatut olukorda, tahab kohut ja õigust ning kasutab sarnaselt esimese kolmandikuga täpselt keskel tunnussõna sĩah $(10,1 \mathrm{~b})$.

${ }^{28}$ Pane tähele ka sõna håkmā markeerivat funktsiooni alastroofide esimestes värssides (12,2b ja $13,5 b)$.
} 
Selles avaldub vormiliselt erakordselt tundlik, tasakaalus ning sisult didaktiline luule. Tugevalt läbikomponeeritud neljavärsilise stroofi näide on Ben Sira 41,17-19.29

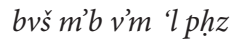
mnšj' všr 'l [khšs]

18 m’dvn vgbr[t] 'lq qšr $m$ 'dh v'm [']l [p]šc

$m s ̌ v t p v r^{\prime} ' l m^{\prime} l$ mmqvm tgvr ['l] jd

19 mhpr'th vbrjt vmmṭth'șjl 'l lhm

\author{
Tunne häbi isa ja ema ees hooletuse pärast, \\ ülema ja ülemuse ees [salgamise] pärast; \\ isanda ja eman[da] ees vandenõu pärast, \\ koguduse ja rahva ees [vas] tuhaku [pä]rast; \\ partneri ja sõbra ees truudusetuse pärast, \\ paiga ees nende [kõrval], kus elad (?); \\ vande ja lepingu murdmise ees \\ ning piiri nihutamise ees toidu pärast.
}

Tarkuskirjandusele on iseloomulik kahest värsipaarist koosnev neljavärsiline stroof. Selliseid on hea kasutada õppimisel, sest värsi-, alastroofi- ja stroofivaheldumise rütm aitavad õpitut paremini meelde jätta. Aga selliseid stroofe on hea kasutada ka lugema ja kirjutama õppimisel: tollal õpiti ülima tõenäosusega tekstid suuliselt enne pähe, kui neid lugema hakati. On loogiline mõtelda, et õppimise juurest astutakse lihtne samm edasi õpitu mõtestamise suunas. Seega on neljavärsiline stroof väga sobiv ka reflekteeriva mureluule jaoks: siin mõtiskletakse, kas õpitu peab vastu elukogemusele ning sellest tulenevale kõige suuremale väljakutsele ehk kannatusele ja murele. ${ }^{30}$

\section{Reeglit kinnitavad erandid}

Kuna Iiobi kõnedes tundub olevat näiteid, mis on sisuliselt kaebused, aga neljavärsiliste stroofidega kõnede koosseisus, või sisuliselt riiukõne, aga esitatud kolmevärsilise stroofina, siis võiks ju ülal toodud eristamises kahelda. Aga vastukaaluks saab väita, et kõne põhitoon on siiski ette antud stroofi pikkusega. Selle järgi tuleb esmalt hinnata, kas kõne põhitoon on afektiivne või reflekteeriv. Kaks esimest Iiobi kõnet ning neljas vastus sõpradele (Ii $3^{*} ; 6-7^{*} ; 16-17^{\star}$ ) on kasutanud algselt ainult kolmevärsilisi stroofe. Nendes domineerivad kaebus, häda kirjeldus, kaosoov, aga on ka episoodilist riidlemist (Ii 6,21-26;16,2-4). Vastupidi valitsevad neljavärsiliste

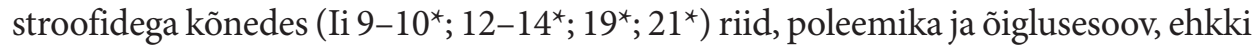
neis esineb vähesel määral ka häda kirjeldust ja kaebust (Ii 14,13*.15-17).

Siinkohal tasub peatuda paaril algset Iiobi dialoogi täiendaval kihistusel, mida sisuliselt ühendab kaduvuse motiiv. Need on samuti osa vanaheebrea mureluulest, ehkki võrreldes Iiobi algsete kõnedega on need selgelt noorema mureluule esindajad.

\footnotetext{
${ }^{29}$ Teksti rekonstruktsioon toetub Pancratius Beentjesi (2006) ja Eric Reymondi (2004) väljaannetele; esitatud on ainult konsonanttekst, sest ükski käsikiri pole vokaliseeritud. Pane tähele läbivat $m$-algriimi.

${ }^{30}$ Vt veel Iiobi kõnede neljavärsilisi stroofe Ii 13,15-16.18-19; 19,2-9.21-24; 21,2-15*.17$18^{*} \cdot 27-34^{*}$.
} 
Ka need kinnitavad reeglit, sest reageerivad Iiobi algsete kõnede stroofistruktuurile, aga ilmutavad samal ajal kergelt muutunud arusaama poeetikast.

Kaduvuse kogemus kuulub kõige põhilisemate hulka inimeste elus ja on tüüpiline universaalse, eksistentsiaalse mure ja mureluule teema. Vana Lähis-Ida tekstides ja Piiblis on näiteid palju, nende hulgas on üks tuntumaid kahtlemata Koguja raamat, mis algab kaduvuse kogemuse deklareerimisega, et valmistada ette pinnast järgnevateks argumentideks. ${ }^{31}$ Tuntuim motiiv säärases luules on rikka ja vaese, ülema ja alama võrdsus surmas. See kajastub Iiobi algses avakõnes 3,13-15.17-19, seega afektiivses toonis kolmevärsilistes stroofides, aga sama teema on üles nopitud ka järgnevalt esitatud hilisemas lisanduses ${ }^{32}$ Ii 21,23-26, mis paikneb reflekteeriva kõne sees ning mõjub sellisena ka sisuliselt.

23

zē jāmūt ba 'eșem tūmmō

kullō šảanān vašălēe

24 'àtāmāòv māla'ū ḥālāb

ūmoaḥ 'aṣmōtāv jašuqqē

25

26 vazē jāmūt banepeš māra

valo'-'àkal batțōbā

jahad 'al- 'āpār jiškābū

varimmà təkassē 'alēhem

Üks sureb otse oma täies jõus,
täiesti 'muretult' ja segamatult;
ta 'reied' on 'rasvast' täis
ja ta liikmete üdi on toidetud.
Aga teine sureb kibeda hingega
ega ole ta nautinud õnne -
kõik nad põrmus heidavad pikali
ja tõugud katavad mõlemat.

Samamoodi, võib-olla isegi sama autori lisatuks tuleb pidada suuremat osa peatükist Ii 14. Kaks stroofi salmides Ii 14,1-2 ja 14,5-10 torkavad silma drastilise väljendusviisi poolest, ehkki ka need on kujundatud neljavärsiliste stroofidena: ${ }^{33}$

1

'ādām jalūd 'iššā

qașar jāmìm ùśaba 'rogez

2 kașịs jāṣă vajjimmāl

vajjbrah kașșēl valo' ja 'amōd

5 'im harūșìm jamav

mispar-hådåšāv 'ittāk<.>

6 ša 'ē mè 'âlāv vahadāl

‘ad-jirșē kəśākīr jōmō

\author{
Inimene, sündinud naisest - \\ napid ta päevad ja küllastunud hirm - \\ nagu õis avaneb ja kahtub, \\ ja ta põgeneb nagu vari ega jää seisma. \\ Kui määratud on tema päevad, \\ kuude hulk Sinu poolest <.>, \\ vaata mööda temast ja 'jäta' ta, \\ et talle meeldiks ta päev nagu teenistujale!
}

\footnotetext{
${ }^{31}$ Teatud tõlketraditsioonide toel on läänekirikus tihti arvatud, et Kogujas räägitakse tühisusest, ent sellele tuleks otsustavalt vastu seista, nagu seda on teinud Kaplinski, Salo 2016 („tühi mis tühi”) ja Padar 2018 („uduaur”).

${ }^{32}$ Vanema teksti vormi on selles lisandis nii hästi järele aimatud, et see petab esmapilgul ära. Seetõttu olen ka varasemas kommentaaris (Nõmmik 2013: 204-205) arvanud, et stroof kuulub algsesse Iiobi kõnesse.

${ }^{33}$ Salmid Ii 14,3-4 on veelgi hiljem lisatud ja on siin välja jäetud. Oma Iiobi kommentaaris (Nõmmik (2013: 174) olen poeemi hilisema päritolu väitmisega olnud liiga ettevaatlik; lisandis võib olla kindel, sest poeem on väga terviklik ja ülejäänud kõnest sõltumatu.
} 
kī jēš lā 'êș tiqvā

'im jikkārēt va 'ōd jahalīp <.>

8 'im-jazqīn bāâreș šåršōo

ūbe 'āpār jāmūt giz'ō

9 mèrēah majim japrīah

va 'āśa qāṣìr kamō-nāța '

10 vageber jāmūt vajjeḥelāš

vajjigva' 'ādām va'ajjō
Jah, puulgi on lootus,

kui ta lõigatakse, siis uuesti puhkeb <.>:

kui jääb vanaks maa sees ta juur

ja põrmus sureb ta kännukönt,

vee lõhnast ta tärkab

ja ajab oksa otsekui võrse;

aga mehepoeg sureb ja nõrkeb

ja kustub inimene - kuhu ta jääb?

Kaks neljavärsilist stroofi kasutavad võrdpilte taimedega: salmis Ii 14,2 õie avanemist, mis võimaldab korralikku algriimi (kașiș jạsṣa $)$, ja salmides Ii 14,7-9 puu surematust, sest luuletaja veendumuse järgi kasvab puu võrsest ikka edasi, kui ka tüvi või känd surevad. Meisterlikult ja sümmeetriliselt korratakse tunnussõnu: see tipneb võtmesõnaga 'ādām 'inimene', mis raamib minipoeemi esimese ja eelviimase sõnana (Ii 14,1a ja 10b). ${ }^{34}$ Sümmeetria suunab tähelepanu kaduvuse suurele antiteesile: alguses on inimene jolūd 'ǐšs $\bar{a}$ 'sünnitatud naisest' (Ii 14,1a), aga lópus geber jāmūt 'mehepoeg sureb' (Ii 14,10a-b), puändiks lühike küsimus va'ajjō 'kus ta on?' või 'kuhu ta jääb?' (Ii 14,10b). Pildikeel on provotseeriv, sest läheb vastuollu traditsioonilise taimemetafoorikaga, mida tarkuskirjanduses kasutatakse reeglina siis, kui konstateeritakse kurjategijate allakäiku (vrd sõprade kõnesid Ii 8,11-13; 15,30-33; 18,16.19).

Põhimõtteliselt võiks ju öelda, et täiendus sobitub ideaalselt reflekteeriva, neljavärsilistest stroofidest koosneva kõne raamesse ning stiilivõtted on sarnased algsete liobi kõnedega. Ent pisuke nihe žanritunnetuses on siiski toimunud, sest värsimõõt ilmutab nooremat tüüpi luule märke. Esimene värsirida kaldub olema selgelt lühem kui teine ehk tegemist on Iiobi raamatus harva esineva pööratud itku värsimõõduga. ${ }^{35}$

Veel ühte kaduvuse motiiviga seotud, aga ühelt või mitmelt täiendajalt pärit Iiobi raamatu tekstide hulka markeerib retooriline küsimus, milles kasutatakse tunnussõna 'enōš 'inimene' (Ii 4,17; 7,1.17; 9,2; 10,4-5; 13,9; 14,19; 15,14; 25,4). Erinevalt tavalisest heebreakeelsest lekseemist 'ādām, nagu ülal kaduvuse refleksiooni näites Ii 14,1.10, on sünonüüm 'enōš arameapärane ja seda peetakse noorema piibliheebrea keele tunnuseks. Selline hiline mureluule on paradoksaalsel kombel seotud kiituslaulu žanriga, sest tendents on eristada selgelt Loojat ja loodut, ülevat ja alandlikku (nii nagu see toimub kiituslaulus Ps 8). Retoorilise küsimuse kujund vaid süvendab efekti. Olgu näitena toodud Iiobi kõnedes väike poeem 7,11-18, mille lisaja ei kavatsegi ennast ega oma muret varjata: „Ka mina, ei taha ma säästa oma suud” (Ii 7,11a), „tahan muretseda [verb śjh] oma hinge kibedust” (Ii 7,11c). Ta kurdab selle üle, et Jumal kiusab košmaaridega isegi öösel, samal ajal kui inimene on universumi mõistes tähtsusetu olend ja kaob kiiresti. Sellist etteheidet peidabki endas küsimus

\footnotetext{
${ }^{34}$ Teised sümmeetriliselt paigutatud sõnad on jāmīm 'päevad' (1b) ja jāmāâv'tema päevad' (5a), jōmō 'tema päev' (6b), jāmūt 'ta sureb' (8b ja 10a).

${ }^{35}$ Viies värsis kaheksast on esimene koolon kolomeetriliselt lühem kui teine: salmis Ii 14,1 (10:14), 14,2 (11:16), 14,6 (12:15), 14,7 (11:15), 14,9 (11:14). Vt ka Ii 7,7-10.
} 
$m \bar{a}$-'enōš kī'kes (küll) on inimene, et...' (vrd Ii 15,14 ja Ps 8,5). Poeemi viimane stroof (Ii 7,16-18) kõlab järgmiselt:

16

mäastì lo'-la 'olām 'ehjēe hadal mimmennī kì-hebel jāmāj

$17 m \bar{a}$-'enōš kì togaddəlennū vakī-tāšit 'èlāv libbekā

18 vattipqadennū libqārìm lirgārìm tibhānennū
Ma hülgasin, ei igaveseks jää elama ma, jäta mind, sest vaid hõng on mu päevad!

Kes on inimene, et pead teda suureks ja et tähele paned teda oma südames; ja et jälgid teda igal hommikul, igal hetkel teda proovid?

See hiljem lisatud kolmevärsiline stroof on omal kohal kõnes, mille algne stroofistruktuur on olnud samuti kolmevärsiline. Vanema kirjandusliku kihistusega sobib ka see, et noorem kolmevärsiline stroof klapib omakorda hümnilise žanriga, mida Iiobi raamatus esindavad näiteks majesteetlikkust või jumalakartlikkust rõhutanud redigeerijad (Witte 1994; van Oorschot 2007; eriti Ii 12,7-25, vrd ka 26,2-4; 28,9-14.2022). Aga kõige rohkem tuleb tunnistada, et afektiivsel ja reflekteerival kaob nooremas mureluules piir. Iiobi algsele teisele kõnele lisatud poeem Ii 7,11-18 tervikuna on poeetiliselt kirjum: esimene stroof (11-12) koosneb ühest tri- ja ühest bikoolonist, ülejäänud kaks stroofi on ehitatud kolmest bikoolonist. Sellele sekundeerib muidu afektiivsele luulele omase 1 . ja 2. pöörde segunemine 3. pöördes ütlustega. ${ }^{36}$

\section{Kokkuvõte}

Väidan esmalt, et vanaheebrea luules on küllalt põhjust rääkida mureluule žanrist. See aitab ületada muidu uurimises ülehinnatud luulekorpuste, nagu psalmi-, prohveti- või tarkuskirjandus, piire ning näha esmapilgul erinevate tekstide vahelisi seoseid. Isegi kui vanaheebrea kirjanduse aegadel ei olnud kedagi, kes oleks mureluulest kui kategooriast mõtelnud, on sellel praeguse aja uurimise edenemise jaoks olemas funktsionaalne roll. Teiseks ei pääse liobi ja ka muu luule võimalikult mitmekihilisest analüüsimisest. Redaktsioonikriitilist uurimist on lihtne süüdistada spekulatiivsuses, aga kes ei eksperimenteeri, see ei loo uusi seoseid. Kolmandaks väidan, et Iiobi dialoogi esimene autor oli teadlik kahest poeetilisest allhoovusest - afektiivsest ja reflekteerivast -, mida ta kajastas vormiliselt, kõige nähtavamalt stroofide pikkusega. Ehkki keskajast pärit Heebrea Piibli käsikirjades ei ole kunagistele stroofistruktuuridele üldse tähelepanu pööratud, on hulga poeetiliste kujundite abil täiesti võimalik eristada kolme- ja neljavärsilisi stroofe. Need on sealjuures korrelatsioonis afektiivse ja reflekteeriva luule alltooniga. Neljandaks väidan, et liobi raamatu nooremates täiendustes, millest arvestatav hulk on seotud kaduvuse motiiviga, on hakanud afektiivne ja reflekteeriv segunema. See kajastub ka vormilistes nihetes, nagu värsimõõdu muutumine pööratud qina suunas või lihtsalt ebastabiilsemaks, veel enam stroofi struktuuri muutumises mitmekesisemaks.

\footnotetext{
${ }^{36}$ Seda tüüpi kaduvuse luule näidetena vt veel Ii 7,1-10; 14,18-22.
} 
Need tähelepanekud ja teesid panevad loodetavasti järgneva uurimise otsima mureluulet ja selle allhoovusi laiemalt Vana Testamendi luulest, ka väljastpoolt liobi, Nutulaulude või Õpetussõnade raamatuid. Aga miks mitte küsida samu küsimusi ka Vana-Mesopotaamia või Ugariti luule kohta, mille uurimisloos on tehtud väga vähe katseid analüüsida stroofistruktuuri.

Uurimistööd on finantseerinud Eesti Teadusagentuur (PRG938 „Piibli liobi raamatu tekkelugu nn liobi kirjanduse taustal").

\section{KIRJANDUS}

Alonso Schökel, Luis 2000. A Manual of Hebrew Poetics. (Subsidia biblica 11.) Roma: Editrice Pontificio Istituto Biblico.

Annus, Amar 2011. Poeem õiglasest kannatajast (Ludlul bēl nēmeqi). - Akadeemia, nr 4, lk 631-652.

Beentjes, Pancratius C. 2006. The Book of Ben Sira in Hebrew. A Text Edition of All Extant Hebrew Manuscripts and a Synopsis of All Parallel Hebrew Ben Sira Texts. (Vetus Testamentum, Supplements 68.) Atlanta: Society of Biblical Literature.

Bright, John 1965. Jeremiah. A New Translation with Introduction and Commentary. (The Anchor Bible 21.) Garden City, New York: Doubleday.

Gesenius, Wilhelm 2009. Hebräisches und aramäisches Handwörterbuch über das Alte Testament. 5. Lieferung $\boldsymbol{3}$-ש. 18. tr. Toim Rudolf Meyer, Herbert Donner. Berlin-Heidelberg: Springer.

Gunkel, Hermann; Begrich, Joachim 1985. Einleitung in die Psalmen. Die Gattungen der religiösen Lyrik Israels. 4. tr. Göttingen: Vandenhoeck \& Ruprecht.

Heebrea keele transkriptsiooni soovituslikud reeglid eesti keeleruumi jaoks. - Mišnatraktaat „Sabat” (Šabbat). Tlk, komm Kalle Kasemaa. (Piibel kontekstis 2.) Tartu: Tartu Ülikooli Kirjastus, 2015, lk 140-148.

Kaiser, Otto 1992. Die Klagelieder. - Hans-Peter Müller, O. Kaiser, James Alfred Loader, Das Hohelied, Klagelieder, Das Buch Ester. 4. väljaanne. (Das Alte Testament Deutsch 16/2.) Göttingen: Vandenhoeck \& Ruprecht, lk 71-198.

Kaplinski, Jaan; Salo, Vello 2016. Koguja raamat. Tallinn: Verb.

Loretz, Oswald 2000. 'Schwarze Magie' des Tages in Hi 3,8 und KTU 1.6 VI 45b-53; 1.14 I 19-20; 1.4 VII 54-56. Zur Überlieferung der 'schwarzen Magie' in Altsyrien-Palästina. Ugarit-Forschungen, nr 32, lk 261-287.

Lugt, Pieter van der 1995. Rhetorical Criticism and the Poetry of the Book of Job. (Oudtestamentische Studiën 32.) Leiden: Brill.

Nõmmik, Urmas 2009. Psalm 22 ja Jeesus ristil. - Et sinu usk otsa ei lõpeks. Pühendusteos Peeter Roosimaale. Toim Andres Saumets, Ain Riistan. Tartu: Kõrgem Usuteaduslik Seminar, Tartu Ülikooli usuteaduskond, lk 9-28.

Nõmmik, Urmas 2010. Die Freundesreden des ursprünglichen Hiobdialogs. Eine form- und traditionsgeschichtliche Studie. (Beihefte zur Zeitschrift für die alttestamentliche Wissenschaft 410.) Berlin-New York: Walter de Gruyter.

Nõmmik, Urmas 2013. Iiobi raamat. (Piibel kontekstis 1.) Tartu: Tartu Ülikooli Kirjastus. 
Nõmmik, Urmas 2015. Vanaheebrea luule poeetika, juhatuseks. - Methis. Studia humaniora Estonica, nr 16, lk 8-26.

Nõmmik, Urmas 2016. Qinah Meter: From genre periphery to theological center - A sketch. - Centres and Peripheries in the Early Second Temple Period (411-436). (Forschungen zum Alten Testament 108.) Toim Christoph Levin, Ehud Ben Zvi. Tübingen: Mohr Siebeck, lk 411-436.

Nõmmik, Urmas; Põldsam, Anu 2018. Psalm 86, its place in the Psalter, and group identity in the Second Temple Period. - Zeitschrift für die alttestamentliche Wissenschaft, nr 3, lk 398-417.

Oorschot, Jürgen van 2007. Die Entstehung des Hiobbuches - Das Buch Hiob und seine Interpretationen. Beiträge zum Hiob-Symposium auf dem Monte Verita vom 14.-19. August 2005. Toim Thomas Krüger, Manfred Oeming, Konrad Schmid, Christoph Uehlinger. (Abhandlungen zur Theologie des Alten und Neuen Testaments 88.) Zürich: Theologischer Verlag, lk 165-184.

Padar, Hanno 2018. Koguja raamatu 1:1-3:15 tähtsamate mõistete eestikeelsete tõlgete võrdlev analüüs. Bakalaureusetöö. Tartu: Tartu Ülikooli usuteaduskond. http://dspace.ut.ee/ handle/10062/60300

Reymond, Eric D. 2004. Innovations in Hebrew Poetry. Parallelism and the Poems of Sirach. (Society of Biblical Literature Studies in Biblical Literature 9.) Atlanta: Society of Biblical Literature.

Rudolph, Wilhelm 1958. Jeremia. (Handbuch zum Alten Testament I/12.) 2. väljaanne. Tübingen: J. C. B. Mohr (Paul Siebeck).

Schmidt, Werner H. 2008. Das Buch Jeremia. Kapitel 1-20. (Das Alte Testament Deutsch 20.) Göttingen: Vandenhoeck \& Ruprecht.

Seybold, Klaus 1996. Die Psalmen. (Handbuch zum Alten Testament I/15.) Tübingen: J. C. B. Mohr (Paul Siebeck).

Seybold, Klaus 2003. Poetik der Psalmen. (Poetologische Studien zum Alten Testament 1.) Stuttgart: W. Kohlhammer.

Watson, Wilfred G. E. 1984. Classical Hebrew Poetry. A Guide to its Techniques. (Journal for the Study of the Old Testament Supplement Series 26.) Sheffield: JSOT Press.

Westermann, Claus 1956. Der Aufbau des Buches Hiob. (Beiträge zur historischen Theologie 23.) Tübingen: J. C. B. Mohr (Paul Siebeck).

Witte, Markus 1994. Vom Leiden zur Lehre. Der dritte Redegang (Hiob 21-27) und die Redaktionsgeschichte des Hiobbuches. (Beihefte zur Zeitschrift für die alttestamentliche Wissenschaft 230.) Berlin-New York: Walter de Gruyter.

Witte, Markus 2006. Schriften (Ketubim). - Grundinformation Altes Testament. Eine Einführung in Literatur, Religion und Geschichte des Alten Testaments. Toim Jan Christian Gertz. Göttingen: Vandenhoeck \& Ruprecht, lk 404-508.

Urmas Nõmmik (snd 1975), dr. theol. habil., Tartu Ülikooli Vana Testamendi ja semitistika kaasprofessor (Ülikooli 18-310, 50090 Tartu), urmas.nommik@ut.ee 


\section{The strophic structure of ancient Hebrew affective and reflective distress poetry, on the example of the speeches of Job}

Keywords: Old Testament, Hebrew Bible, poetry, biblical poetry, strophe, verse

The paper suggests that there is enough reason to maintain the genre of distress poetry in Ancient Hebrew poetry. It helps to overcome the limits of the poetical corpora of psalms, prophets and wisdom overestimated so far in research history, and to see connections between texts that seem different at first glance. Even though in ancient times there seem to have been nobody to consider the category of distress poetry, it still has a functional role nowadays. The present small study requires a multilayered, redaction-critical look at the Book of Job and other poetical texts, which reveals hitherto unnoticed relationships between the texts. The paper focuses, however, on the distinction between affective and reflective undercurrents in the distress poetry. The first poet of Job was aware of the distinction and made it visible in form by varying the length of the strophes. As for the speeches of Job, a considerable number of poetical figures help us to delimit the original strophes of three and four bicola, correlating with the affective and reflective undercurrents, respectively. The speeches with an original structure of three bicola per strophe mostly lament and describe the distress (Job $3^{*} ; 6-7^{*} ; 16-17^{*}$; examples discussed in 16:12-16*; $\left.6: 8-13^{\star} ; 3: 3+7-8^{\star}+10-12\right)$, whereas the speeches with four bicola per strophe quarrel and polemicize with friends and God, and plea for righteousness $\left(9-10^{*} ; 12-14^{*}\right.$; $19^{*}$; $21^{*}$; examples 9:15-16*+19-20+27-28+30-31; 12:2- $\left.3^{*}+13: 5-6\right)$. Support for the three-part strophes can be drawn from lamentations, like those in the Book of Lamentations (e.g. 2:11-12), and for the four-part strophes from traditional didactic poetry, such as in the Book of Ben Sira or, found in its most regular form, in the Masada manuscript (e.g. 41:17-19). Furthermore, the paper discusses a few examples of the motif of transience in some younger literary additions to the speeches of Job (21:23-26 and 14:1-2+5-10* of one type and 7:16-18 of another, the so-called 'enōstype). In those, the affective and reflective undercurrents start to mix, which can be observed through formal shifts, e.g., in the verse metre of inverted Qinah or in the use of a more complex strophic structure.

Urmas Nõmmik (b. 1975), dr. theol. habil., University of Tartu, Associate Professor of Old Testament and Semitic Studies (Ülikooli 18-310, 50090 Tartu), urmas.nommik@ut.ee 